専門医症例報告

下顎骨腫瘍摘出後に骨移植とインプラント補綴で対応した症例

大堀ことは

\title{
A Case of Prosthesis Using Bone Graft and Dental Implants for Mandibular Defect Following Tumor Extirpation
}

Kotoha Ohori

\begin{abstract}
抄 録
症例の概要：患者は初診時 15 歳女性で，オトガイ部から左下顎骨体部の腫脹と疼痛を主訴に来院した。 エナメル上皮腫と診断され，腫瘍摘出と同時に $2+3$ を抜歯した。 下顎骨欠損は広範囲に及んだため，欠 損部顎堤に腸骨を移植し，インプラントによる補綴処置を行った。

考察：審美と機能を考慮した欠損部への骨移植とインプラント補綴を行うことにより患者の QOL が向上 した。 また，インプラント体周囲の骨吸収，軟組織の炎症反応はほとんどなく，補緅処置は良好な経過が 得られたと考えられた。

結論：下顎エナメル上皮腫摘出後に生じた広範な顎欠損に対し，自家骨移植を行った後にインプラント補 綴を行うことにより，審美および機能が回復され，良好な経過が得られた。
\end{abstract}

和文キーワード

インプラント補綴，自家骨移植，エナメル上皮腫，下顎骨欠損

\section{ABSTRACT}

Patient: A 15-year-old female complained of swelling and pain from the mental region to the left side of the mandible. The pathological diagnosis was ameloblastoma. The tumor, anterior teeth, and left canine on the lower jaw were extirpated. Since the missing part of the mandible was large, autogenous bone from the ilium was grafted therein. Following this, implants were inserted and implant-supported fixed prostheses placed theron.

Discussion: Bone graft for the missing part of the mandible and dental implants improved the patient's QOL both esthetically and functionally. Inflammation of the soft tissue and resorption of bone around the implants were scarcely observed and the prostheses showed no complications.

Conclusion: Autogenous bone grafts and dental implants for missing parts of the mandible after extirpation of ameloblastoma can provide esthetic and functional improvement, and are useful to obtain a satisfactory prognosis.

\section{Key words}

implant-supported fixed prostheses, autogenous bone graft, ameloblastoma, missing part of mandible

北海道大学大学院歯学研究科口腔機能学講座口腔機能補綴学教室

Department of Oral Functional Prosthodontics, Division of Oral Functional Science, Graduate School of Dental Medicine, Hokkaido University

受付 : 2009 年 12 月 22 日/受理：2010 年 4 月 20 日

Received on December 22, 2009/Accepted on April 20, 2010 


\section{I. 緒 言}

下顎腫瘍摘出後に生じた広範な顎骨欠損に対し，自家 骨移植と同部へのインプラント補経を行うことにより， 審美および機能が回復され良好な経過が得られたので報 告する.

\section{II. 症例の概要}

患者：15歳，女性.

初診: 平成 3 年 4 月 17 日.

主訴：オトガイ部から左下顎骨体部にかけての腫脹と 疼痛.

診断：エナメル上皮腫（図 1).

特記事項：歯科恐怖症。

初診より, 当院口腔外科にて開空術を繰り返し, 経過 観察を行っていたが，平成 8 年 3 月, $\overline{21 \mid 123}$ の動 摇が増大し， 123 は歯根露出が根尖付近まで及んだ。 下顎腫瘍摘出と同時に $21 \mid 1223$ の抜歯を行うこととな り, 口腔外科より抜歯後の即時義歯製作依頼で, 補綴科 受診となった。

担当までの経過 :

1) 補経科初診: 平成 8 年 3 月, 20 歳.

2) 現症: $\overline{21 \mid 123}$ は動摇度 3 であり, 123 の歯 根は露出していた。厉には咬耗が観察され，夜間のパラ ファンクションが疑われた。 また，右側方運動時に左臼 歯部に干渉か認められた。 5 は位置異常のため対合歯と の咬合接触がなかった。

平成 8 年 3 月, 下顎腫瘍摘出および $21 \mid 123$ 抜歯 直後に，支台装置として $54 \mid 45$ に双歯銁を，大連結装 置としてリンガルバーの設計を行った即時義歯を装着 し，義歯調整を行つた。

下顎前歯および同部顎骨欠損による審美障害の診断の もと, 患者が歯科恐怖症であり, 侵襲を伴う処置を必要 最小限にすることを希望していること，また，下顎の骨 欠損範囲が大きく,さらに腫瘍の再発の危険性を考慮し, 前医は，可撤性部分床義歯を補綴装置として選択し，審 美および咀嚼機能の回復を行うこととした。

平成 9 年 2 月，支台装置として $43 \mid 45$ にレスト付 二腕鉤を，大連結装置としてリンガルバーの設計を行っ た下顎義歯を装着したが，数力月後には，患者は，審美 的理由から義歯の使用が困難であることを訴え，固定性 補綴装置を強く希望した。 欠損部に腸骨移植を行った後 に，ブリッジもしくはインプラント支持の補綴装置に関 する説明を十分行った結果，手術回数に対する抵抗感な

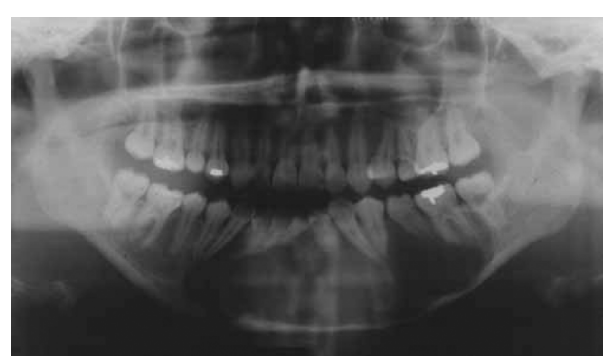

図 1 Panoramic radiography at the first examination 初診時のパノラマX $\mathrm{X}$ 線写真

どからブリッジを希望した。

平成 10 年 2 月，欠損部顎堤に，腸骨移植による下顎 歯槽堤形成術を行い, (4)(3)2 $1 \mid \begin{array}{lll}1 & 2 & 3\end{array}$ (4)(5)プロビジョナ ルレストレーションを装着した。

\section{III. 治療内容と経過}

\section{1. 治療内容}

平成 10 年 6 月，前医から引き継ぎ，欠損部顎堤の変 化に対応して, プロビジョナルレストレーションの調整 を行い，ポンティックの基底面形態は離底型とした（図 2)。しかし，移植骨の吸収が進み，審美的改善が困難 なため, 同年 11 月，骨移植を再度行った。 また，患者 のインプラントへの関心が高まったこともあり，十分な インフォームド・コンセントを行い, 移植の後に, イン プラントによる補綴処置を行うこととした。

診断：移植骨吸収と下顎前歯部欠損による審美障害.

治療方針：下顎欠損部への骨移植とインプラントによ る補綴処置を行うこととした。

平成 11 年 10 月, 腸骨移植を実施し（図 3), その後, 模型上でワックスアップを行い，最終補経装置の被蓋関 係を決定し，インプラント体の埋入方向を決定した。埋 入位置は， $\overline{2 \mid 3}$ 相当部が理想であったが，骨量，骨幅が 明らかに不足していたため, $\overline{1 \mid 12}$ 相当部とした.

平成 12 年 3 月, $1 \mid 12$ 相当部にフィクスチャー (STERI-OSS, $\phi 3.25 \mathrm{~mm}$, 長さ $16 \mathrm{~mm}$ ) を埋入し, 十 分な初期固定がなされていることを確認した， 8 月， 2 次手術を行い，ヒーリングアバットメントを装着した。 11 月，アバットメントを装着し， 2 (1)|(1)(2)3および残 存歯 $43 \mid 45$ にプロビジョナルレストレーションを装 着した，偏心運動時のガイドは，右側方運動時は 43 と 43 , 左側方運動時は $\lcm{34}$ と $\longdiv { 3 4 }$, 前方運動時は $1 \mid 1$ と $21 \mid 1$ とした.

平成 13 年 6 月，プロビジョナルレストレーションに よる十分な経過観察後， 2 (1)|(1)(2) 3 にインプラント支 

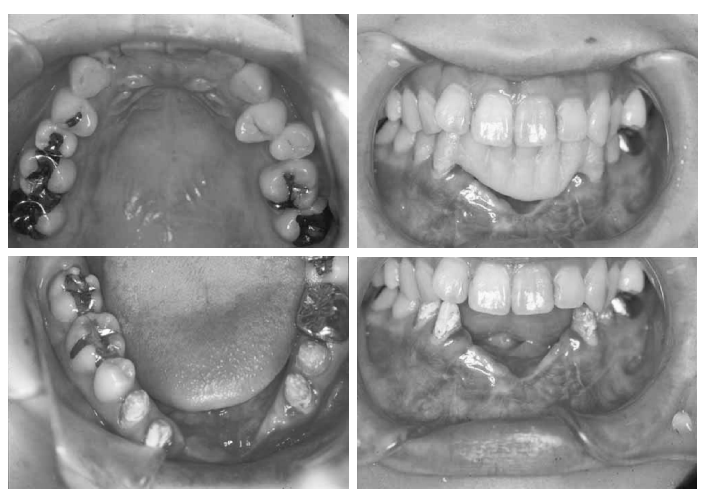

図 2 Intraoral views in be taken over 引き継ぎ時の口腔内写真
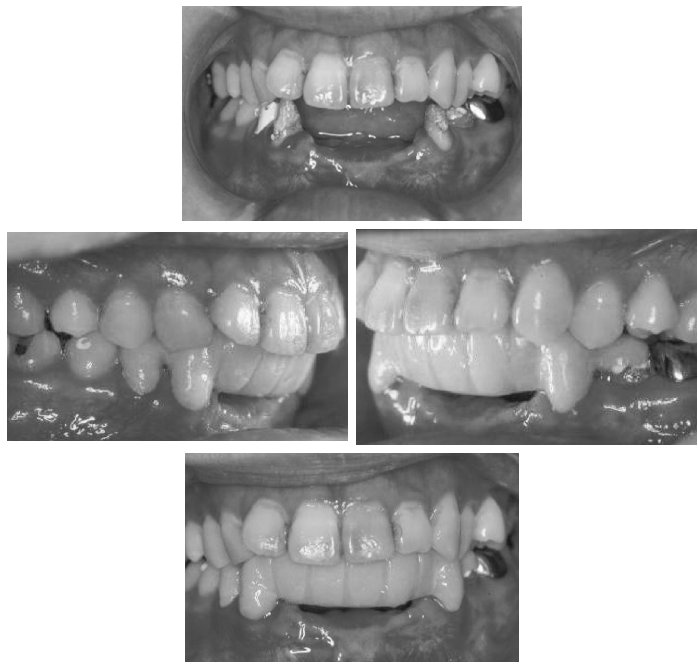

図 3 Intraoral views after bone graft from ilium 腸骨移植後の口腔内写真
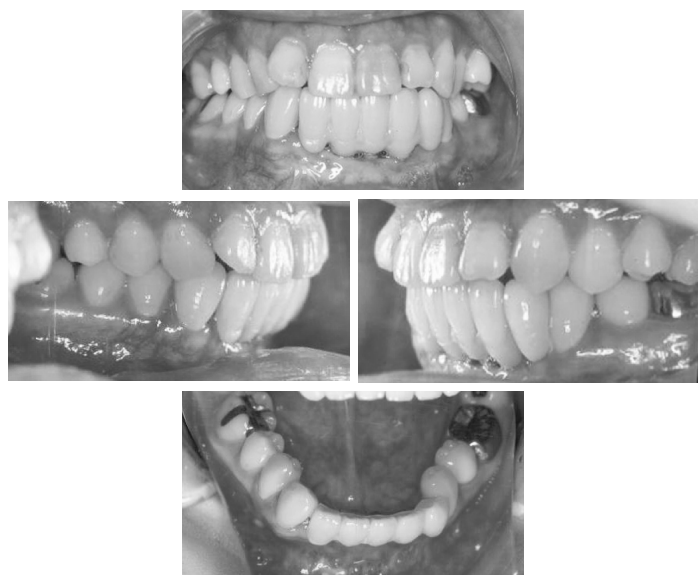

図 4 Intraoral views after placing of prostheses 最終補綴物装着後の口腔内写真

持の陶材焼付鋳造ブリッジ，残存歯 $\overline{43 \mid 45}$ には陶材
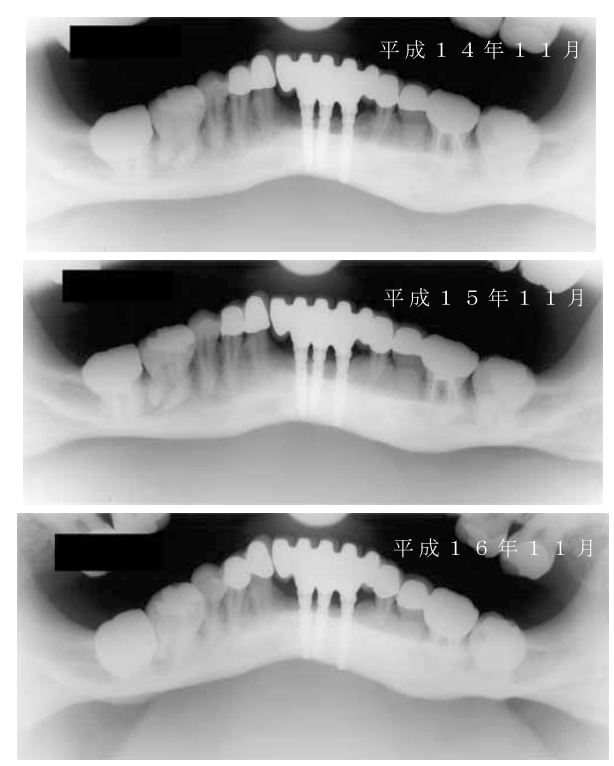

図 5 Intraoral source panoramic radiography 口腔内線源方式パノラマ X 線写真

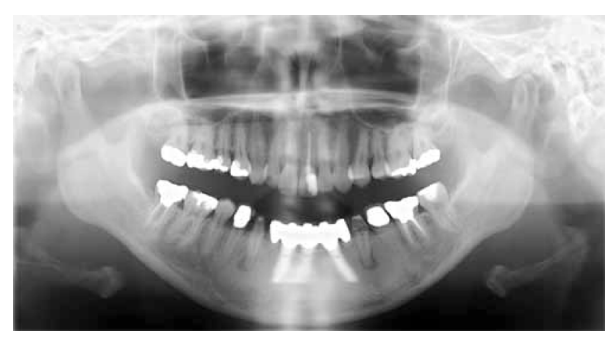

図 6 Panoramic radiography in April in 2007 平成 19 年 4 月, パノラマX線写真

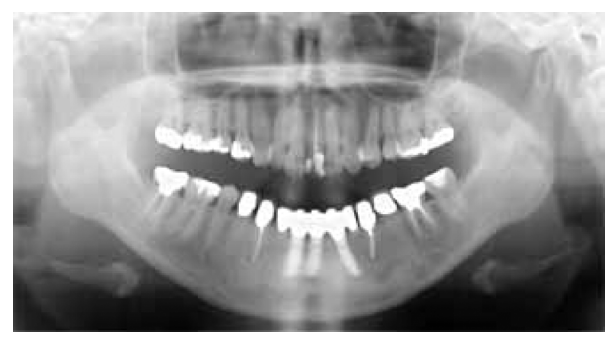

図 7 Panoramic radiography in November in 2008 平成 20 年 11 月, パノラマ $\mathrm{X}$ 線写真

焼付鋳造冠を単冠で装着した（図 4).

\section{2. 経過}

インプラント治療終了から約 7 年間， 6 カ月ごとのリ コールを行っている。移植骨の吸収はほとんどなく（図 5), インプラントを含めた補綴装置にも大きな変化も なく，良好な状態を保っていた。平成 19 年 3 月，側方 
運動時のガイドに関与する $\overline{3 \mid 4}$ に慢性根尖性歯周炎が 生じ (図 6), 根管治療後, 根尖部透過像の縮小傾向が 認められた。プロビジョナルレストレーションにて咬合 調整を慎重に行い, 磨耗や仮着材の溶解がないことなど 十分な確認を行い，平成 20 年 9 月，陶材焼付鋳造冠を 装着した（図 7).

\section{IV. 考 察}

本症例は，エナメル上皮腫摘出後に，骨移植ならびに インプラント補綴を行った症例である，患者は若い女性 であり, 欠損部位が審美性に強く影響する部位であった ため，固定性補経装置の装着を強く希望した。審美およ び機能に対する患者の希望を考慮し，欠損部への骨移植 とインプラント補綴を行うことにより，患者の QOL が向 上し,十分な満足を得ることができたと思われる ${ }^{1)}$ (図 8). 骨移植に関して, 初回の骨移植では吸収が進行したが, 2 回目の移植では予後が良好であった.この理由として, 初回の骨移植では, 最終補綴装置をブリッジとする予定 であったため，骨移植を小範囲にし，粉砕した腸骨を移 植したため，瘢痕拘縮を起こし，吸収が進行したが，2 回目の骨移植では，ブロックの骨をスクリュー固定した ので吸収がなかったものと考えられる。

インプラント支持の補綴装置に付与すべき咬合接触に 関しては，過度の側方荷重を付与した場合にオッセオイ ンテグレーションが品失するという報告がある ${ }^{2,3)}$. 本 症例では, 3 がカンチレバーになっているため, 咬合の 設定にあたり，側方運動時 4 , 4 ガイドとしたが，過 重負担にならないよう厉に加え| 3 のカンチレバーを軽く 滑走させた。これによるインプラント体への影響は認め られていない．偏心滑走運動時に発現する側方力を分散 させるために， 5 ， 5 のガイドへの参加も検討したが, 古の位置異常のためできなかった.

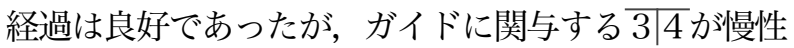
根尖性歯周炎となった，原因として，ガイドの展開角が 強すぎたことが考えられたため, 再補綴処置では, プロ ビジョナルレストレーションでこの点を考慮し，仮着材の 溶出や咬耗を十分観察した後, 最終補綴装置を装着した。

加えて, 初診時検査において, $\sqrt{3}$ に強い咬耗が認めら れたことから，夜間のパラファンクションが疑われた。 そのため, インプラントだけでなく顎口腔機能の管理と して夜間はナイトガードを装着している.

今後も, リコール時に，インプラントを含めた咬合や 補綴処置の適切な管理や指導が引き続き必要である.

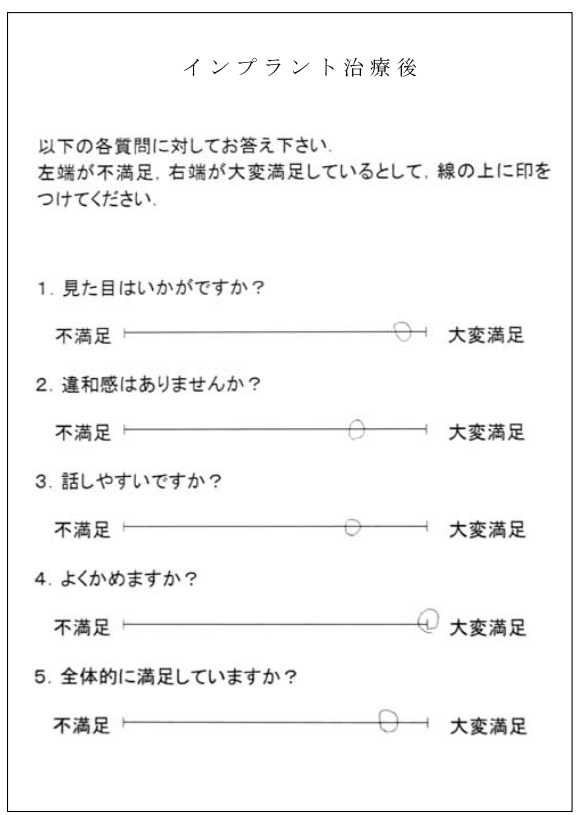

図 8 Evaluation of patient satisfaction 満足度評価 ${ }^{1)}$

\section{V. 結 論}

下顎エナメル上皮腫摘出により生じた広範な顎欠損に 対し, 自家骨移植と同部へのインプラント補綴を行い, 審美および機能を回復するとともに QOLが向上し，良 好な経過が得られた。

\section{文献}

1）若林則幸，谷田部優，佐藤雅之，中村和夫，岡部良博, 藍 稔. 新たな部分床義歯製作を希望した患者の心理的 傾向についての評価。補経誌 1997; 41: 106-111.

2) Isidor F. Loss of osseointegration caused by occlusal load of oral implants. A clinical and radiographic study in monkey. Clin Oral Impl Res 1996; 7: 143-152.

3) Isidor F. Histological evaluation of peri-implant bone at implants subjected to occlusal overload or plaque accumulation. Clin Oral Impl Res 1997; 8: $1-9$.

著者連絡先 : 大堀ことは 于 060-8586 札幌市北区北 13 条西 7 丁目 TEL: 0 $11-706-4270$

FAX: 011-706-4903

E-mail: kotoha@den.hokudai.ac.jp 